\title{
The New Actors of the Society in Social Policies of Attendance to the Children and the Adolescents in Brazil
}

\author{
Eric Ferdinando Kanai Passone* \\ Researcher Associate of, University of São Paulo, São Paulo, Brazil \\ *Corresponding author: ericpassone@yahoo.com.br
}

Received December 19, 2013; Revised February 15, 2014; Accepted February 17, 2014

\begin{abstract}
In the field of analyses of public policy, this research is dedicated to the study about the emergence of new actors of the civil society in social policies of attendance to the children and adolescents in Brazil. The object of this work was to analyze the performance of the non-governmental organizations for the rights of children and adolescents in the Brazilian context of state reform. As results, we can emphasize the position some nongovernmental organizations, as a social actors that differs from non-profits organizations acting in the so called "third sector". Meanwhile, there are groups that criticize the inefficiency of the State, putting the supremacy of the marketas potential substitutes of the State. The political action of these organizations, characterized by dialogue, mobilization, participation, that is aiming at qualification of the state, the accountability of public policies, and the reinforcement of the civil society.
\end{abstract}

Keywords: Brazil, democratic participation, education, social policy, rights of children and adolescents

Cite This Article: Eric Ferdinando Kanai Passone, "The New Actors of the Society in Social Policies of Attendance to the Children and the Adolescents in Brazil." American Journal of Educational Research, vol. 2, no. 2 (2014): 97-101. doi: 10.12691/education-2-2-5.

\section{Introduction}

The social policy debate has been gathering more and more sectors and interests in the globalized world, especially policies of attendance to the children and adolescents. The process of institutionalizing childhood and adolescent's rights, during the 20th century, corresponds historically to the economic, political and cultural changes that took place in the contemporary State [1,2].

On the issue of social protection system, the institutional restructuring process of social policies was guided towards globalized competitive economy and economic restrictions. In the same sense, the dilemma established in the 90's was regarding the conciliation of economic growth and combination of State and Society's social responsibilities towards the creation, articulation and management of public policies in a scenario lacking public resources on one side and a social democracy demand on the other side.

In this scenario, the sense of collaboration, partnership and social media have become usual vernacular to social policies managers, formulators and executors whether it is in state sections such as "non-state" or "third sector". As a result, the participation of civil organizations assumed a quite peculiardefinition in the State's administrative modernization process, based upon the social service offer, on state programs decentralization, efforts of government and private sector around better integration and rescue systemic energies $[3,4]$.

The social expenditure started to be ordered by a managerial model of sustainable development destined to elevate effectiveness and efficiency standards in social investments. This process represented, in many countries, a fundamental remodeling regarding the nature of attendance services (healthcare, education, social welfare, job generation, household and the like) with the strengthening of private social activities (profitable and non-profitable ones), i.e, re-organizing the interdependence between Civil Society and the State with the emergency of a nongovernmental public space potentially able to intervene in the State [5].

Thus, it has been observed in the last decades the appearance of "new" social actors in the social policy attendance to childhood and teenagers' field, for instance, the entrepreneurial foundations and non-profitable associations.

From the theoretical point of view the conflicts related to the implementation of social services inside the society are divided in two big perspectives that portray distinct forms of articulation among the State, society and the market. It is possible to affirm that such perspectives dispute the hegemony of their politics projects in the public space reflecting both a residual and liberal pattern or an institutional and redistributive pattern (socialdemocrat) of Welfare State in accordance with Titmuss' models and Esping-Anderson's. [6,7] With a more liberal viewpoint, the private social services operate in the same market logic, in a dispute for its own interests in the "nonstate" field. The term "third sector", as an example, portrays the maximization of the actions between the market and the society. In this perspective, the market sustains social actions in the quest for its own benefits such as the strengthening of the brand, tax deduction, 
social marketing and citizenship of consumption, devaluating the broad concept of society as the arena for political self-organization.

On the other hand, the notion of what society means must not be mistaken with private public sector supported by market structures or social goodwill actions, but it is characterized by heterogeneous actions from social organizations that have the goal to participate in the State through multiple ethnic-political projects whether it is through creation of co-management spaces and proposal elaboration or executing complement or policy implementation. In this perspective, the society participates in the structural transformation of state-society binomial not being restrained only to modern philanthropy actions and entrepreneurial citizenship [8,9].

For this reason, the aim of the present study is to investigate the policies to the youth attendance in Brazil in the last 20 years, identifying the role of the "new" social actors of society such as the non-governmental organizations for the rights of child and adolescent, focusing in the relation with the state and the policy of infant-juvenile attendance in Brazil.

The 'new institutional' approach was used to analyses of public policies, basically aiming the historical delimitation of the "scenario" or the instituted context of the social policy proposed to children and adolescents in Brazil. That is developed in the first part this paper Scenario: democratic achievement of child and adolescent rights. The study also identified some organizations called "public and non-government", which work on the attendance of social policies, representing the society's participation. Such social organizations were the basis for the theoretical discussion on different perspectives that assume the role of interface among the society, the State and the market, according to the adopted reference presented in the second part The new actors of the society in attendance of child and adolescent attendance policy.

In order to identify the role of the society's organizations in the attendance of this policy was carried a case study based upon the review of literatures, legislation, documents and reports. It was analyzed the performance of Abrinq Foundation for Rights of Child and Adolescent in the relationship with the State. This case study was as a result of the master's degree graduate entitled The social policy of infant-juvenile attende: the case study of Abrinq Foundation.

Two research hypotheses have been formulated: i) the participation of society has been highlighted due its capability of providing qualified information about social demands and efficiently acting on public activities execution destined to social demands $[4,8,9]$ there are groups and organizations that criticize the State's inefficiency and establish the market' and society's supremacy as potential substitutes for the State, on the other hand also there are organizations, as social actors, being different from non-profitable groups or entities inserted in the third sector or non-governmental public space $[9,10]$.

As results, it is possible to highlight the ambiguous positions of some organizations characterized by dialogue, mobilization and participation which aim the governmental capacitation, the public policies monitoring, strengthening of governmental management, qualification of electoral debate on childhood and teenager attendance policies and the mobilization of the society and the market regarding the child and adolescent rights.

\section{Scenario: Democratic Achievement Of Child And Adolescent Rights}

In Brazil, the emergency and consolidation of social policies related to young people can be put on a system in two great periods, to be known, before and after the creation of "Estatuto da Criança e do Adolescente" (ECA) (Child And Adolescent's Statute) [11].

The main criterion of delimitation between these two periods is the conception about infancy and adolescence implicit in the juridical structure from these different periods: on the one side there is the conception that represented the institutionalization of infancy, as a controlling tool used by part of Brazilian government, in the period that portrays policies and conceptions from the early years of the Republic, and which goes from the beginning of the 20th century until the end of military dictatorship, in 1985; on the other side there is the period of democratic opening in the country that wound up in the year of ECA promulgation (1990), whose idea of infancy and adolescence received a status of subjects of rights portraying the deep change the Statute represented in legislative, normative, cultural and conceptual terms and in the guidelines for public policies and services destined to the attendance of children and adolescents in Brazil $[1,10]$.

After decades of ambiguous social policies, and for many times violent and repressing, destined to the social care of children and adolescents, the infancy and adolescence matter reached the political agenda as a right. With the intervention of organized social movements and political representatives, an institutional-and-juridical new order emerged bringing the childhood notion to the condition of a group of subjects with rights and duties. The articulation among human rights entities, NGOs, entrepreneurial foundations, religious entities, UNICEF, United Nations, and the like, represented society's wide participation who was mobilized supporting a policy of child and adolescent rights.

This historical moment was widely recognized in the recent process of constitution and strengthening of a democratic society and its respective public sphere as political process originated from years of struggle against authoritarian political periods reclaiming a social organization for civil, political and social rights through social justice and juridical ensuring of citizenship rights [8].

As an unfolding of this period, the National Constitution of 1988 redefined, in articles 227, 228 and 229 , the position and representation of children in the society acknowledging them as subjects with rights and full protection. The link between the country's legislation and the international laws was thus established, just as the Children's Right Convention, approved by UN's General Board in 1989, whose principles "match in one legal body civil and political rights with economic, social and cultural rights considered as complementary components necessary to ensure full protection of children and teenagers" [2].

Through regulation of the Federal Constitution, the following legislations were constituted based on social 
rights: the Child and Adolescent's Statute (Federal Law n. 8,069/90), Healthcare Organic Law (Federal Law n. 8,080/90); the creation of the National Council of Children and Adolescent's Rights (Federal Law n. 8,242/91); Social Welfare Organic Law (Federal Law n.
8,742/93), Law of Guidelines and Bases of National Education (Federal Law n. 9,394/96); Organic Law on Security Food and Nutrition (Federal Law n. 11,346/06) besides the recent integration of social services via Unified Social Assistance (Table 1).

Table 1. Social Protection of childhood and adolescence attendance in Brazil (1988 - 2006)

\begin{tabular}{|c|c|c|}
\hline $\begin{array}{l}\text { Social Policy's } \\
\text { Dimension }\end{array}$ & Social Protection & Main Characteristics \\
\hline \multirow{3}{*}{ Social rights } & & New political, juridical and social standards \\
\hline & Federative Republic of Brazil's Constitution (1988) & \\
\hline & & Institutionalization of childhood and adolescence as subjects with rights \\
\hline \multirow{2}{*}{$\begin{array}{c}\text { Child } \\
\text { And } \\
\text { Adolescent's } \\
\text { rights }\end{array}$} & $\begin{array}{l}\text { Adoption of Children's Rights International Convention } \\
\text { (Legislative Decree n. } 28 \text { from 1990) }\end{array}$ & \\
\hline & $\begin{array}{l}\text { Child and Adolescent's Statute (Law n. 8,069 from } \\
\qquad 1990 \text { ) }\end{array}$ & Decentralization, Municipalization, control and social participation \\
\hline Health & $\begin{array}{l}\text { Unified Healthcare System (Health Organic Law n. } \\
\text { 8,080 from 1990) }\end{array}$ & $\begin{array}{c}\text { Consolidation of a social protection system (healthcare, social security, } \\
\text { education, social welfare and development work) }\end{array}$ \\
\hline Education & $\begin{array}{l}\text { Law of Guidelines and Bases of National Education } \\
\text { (Law n. 9,394 from 1996) }\end{array}$ & \\
\hline Social welfare & $\begin{array}{l}\text { Unified system of Social Welfare (National Policy of } \\
\text { Social Welfare - Resolution CNAS n. } 145 \text { from 2004) }\end{array}$ & \\
\hline
\end{tabular}

The legislations started to ensure the guidelines for basic social policies with capability of offering conditions to essential needs such as healthcare, education, culture, food, sport, leisure and professionalization, considering access to social rights a dimension of citizenship. [12]The Child and Adolescent's Statute, promulgated on July 13th, 1990 substituted the repressive doctrine of 1979's "Underaged Code" and implemented new political, juridical and social references, defining that every child and adolescent have the right of full protection. The ECA expresses, therefore, the children and teenagers' rights and guides all the system of right ensuring and social policy.

The Statute was constituted by four dimensions:

a) universal basic social policies such as healthcare, education, habitation and the like (art. 87, item I).

b) the policies and programs of social welfare (art. 87, item II) with supplementary characteristic to those who need them. c) protection policies that represent special services of medical and psychosocial attendance to neglect, mistreatment, exploitation, abuse and oppression victims (art. 87, item III); Identifying and locating services for parents or responsible and missing children and adolescent (art. 87, IV).

d) and the policies of right ensuring that represent juridical and social entities and apparatus of individual and collective right protection of childhood and adolescence.

The Right Ensuring System supports all policies of childhood and adolescence under three acting axes: social promotion, defense and control. These actions are promoted by the Public Power (inside its scopes - Union, states, Federal District and municipalities - and Executive, Legislative and Judiciary Powers) and by the Civil Society intending to fulfill and execute what is presupposed by ECA (Figure 1).

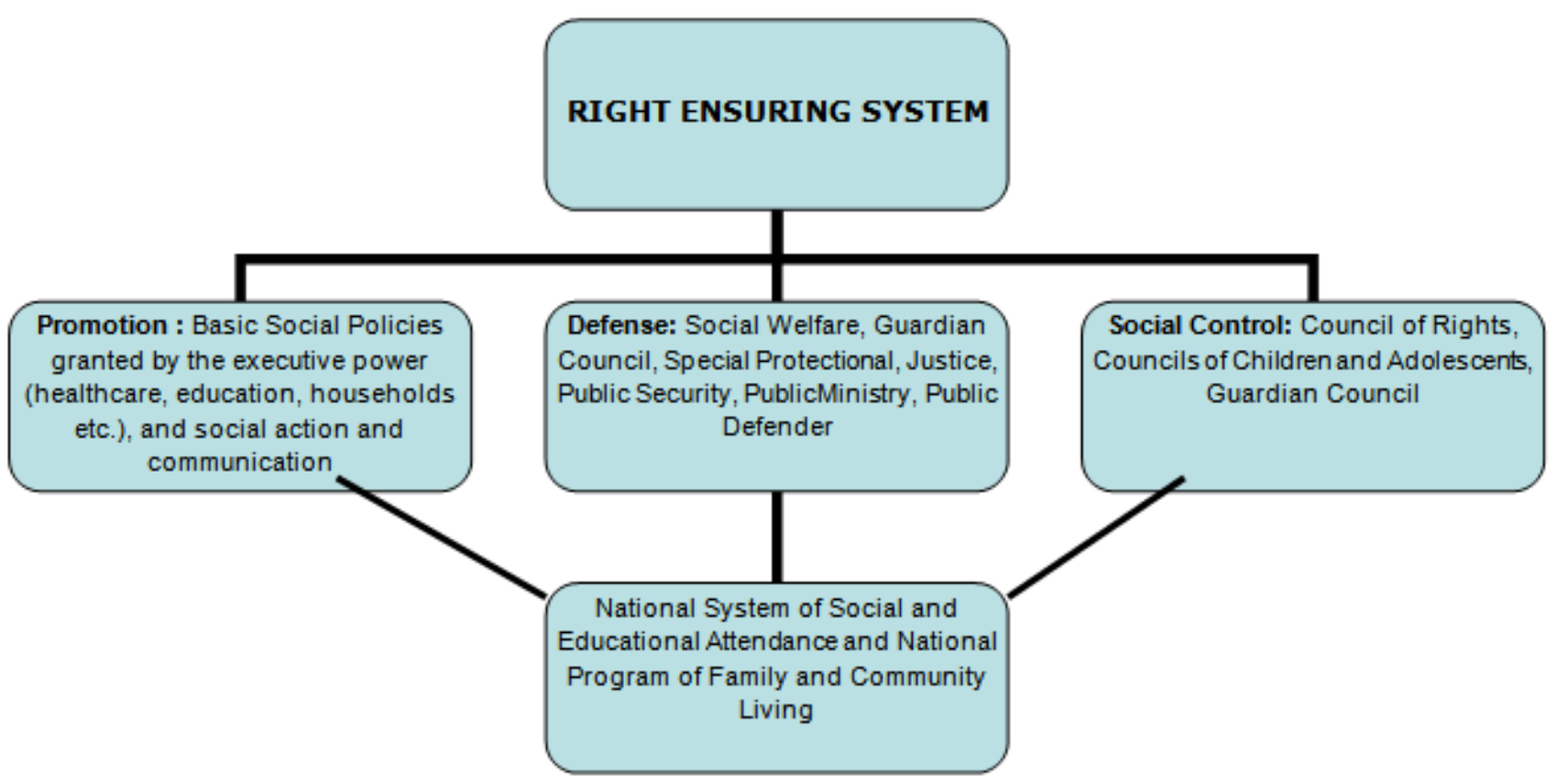

Fihure 1. Social-juridical Layout of Right Ensuring Systems 
The main guidelines that compound this policy are: municipalization, decentralization, creation and maintenance of specific programs; creation of municipal, state and national councils for children and adolescent rights (as spaces of deliberation and control of actions in all levels ensured by social participation) according to federal, municipal and state laws; the maintenance of state and municipal resource funds; awareness of public opinion on the participation in several society segments and operational integration of judiciary, public right defense and social welfare departments [11].

\section{The New Actors of the Society in Social Policies of Attendance to the Children and Adolescents}

In Brazil it is recent the perception that foundations and non-profitable organizations form a group or a "sector" with substantial representative specific interest in the area of social policies. Despite this new activity of social sectors, the figures reveal that organizations defined as private foundations and non-profitable associations have been increasing: from 1996 to 2005, from 107 thousand to 338 thousand organizations, representing an increase of 253\%. Studies demonstrate that sector it was responsible for employing 5.3\% of Brazilian workers, representing 1.7 million people who earned an average of US\$440 (figures from 2005) a month [13].

The significant growth of private foundations and nonprofitable associations brought up some debates on the redefinition of the State's role, focusing in democratic participation, in accountability and in discourses of the ethnic and cultural identity (Brooks 2004).

For Landim [4], studies and debates focused mainly the role of non-profitable organizations in the relation with other Brazilian society's sections, especially the State and its capacity to solve social reclamation originated from poverty and social differences. Some of the debated topics around of Social organizations' role were related to resources available, its action as a State's extension or as a substitute and its capability to implement and influence public policy, i.e., its competence, effectiveness and potential to manage poverty $[9,10]$.

In Brazil data display that $34 \%$ of the activities developed by non-profitable foundations and organizations acted on the governmental policy area such as healthcare, social welfare, habitation, environment, culture, education and research. The associated activities such as community associations, community organizations, associations of professionals, rights defense and citizen's interest, rural development, employment and training and entrepreneurial associations represented more than one third (35.2\%) of the organizations. Other 25\% represented entities that spread their religious principles (Table 2).

Table 2. Number of Private Foundations and Non-profitable Associations, according to acting area - Brazil - 2005

\begin{tabular}{|c|c|c|}
\hline \multirow{2}{*}{ Classification } & \multicolumn{2}{|c|}{ Non-profitable Associations and Foundations* } \\
\hline & $\mathrm{N}$ & $(\%)$ \\
\hline ProfessionalsandEmployers' Associations & 58.796 & $17,4 \%$ \\
\hline Social Welfare & 39.395 & $11,6 \%$ \\
\hline Culture & 46.999 & $13,9 \%$ \\
\hline RightDefenseAdvocacy & 60.256 & $17,8 \%$ \\
\hline EducationandResearch & 19.940 & $5,9 \%$ \\
\hline Habitation & 456 & $0,1 \%$ \\
\hline Environment & 2.562 & $0,8 \%$ \\
\hline Health & 4.464 & $1,3 \%$ \\
\hline Religion & 83.775 & $24,8 \%$ \\
\hline N/A & 21.516 & $6,4 \%$ \\
\hline TOTAL & 338.159 & $100,0 \%$ \\
\hline
\end{tabular}

Source: IBGE, Diretoria de Pesquisas, Cadastro Central de Empresas [12]

* The criteria followed to classify this organization group: private, non-profitable, institutionalized, self-administrated and volunteer

These data demonstrate that the organization's and the search for an "active, wide and volunteer performance on attendance of social policies reveals the participation which realizes the miracle of donative heterogeneous profile of the society, attending several citizenship" [9]. areas mainly in relation to the State and public policies. Such confirmation reinforces the importance of the studies about limits between the public and private spheres and consequently investigates thestructuring of public scope and democratic quality over issues regarding social classes that are outcast and tend to be social groups taken over by activities of third-sector organizations.

Based on what has been exposed in this text, it is possible to observe that the intervention of organizations on social policy attendance tends to follow the logic of "civil modernity fulfillment, implemented with emphasis in the market field". This way, it has represented the "instrumental rationality common in market management"
For instance, the Foundation, Institute and Enterprise Group, which searches the generation of a "citizenship consciousness" inside the Brazilian entrepreneurial class through entrepreneurial activities investment in social issues. This kind of the participation is restricted to the strengthening of third-sector entities and to defense of private section's social initiatives, keeping their interests in the area of social and resource search [10].

In the matter of childhood and adolescence attendance policies, we choose as an example the case study Abring project, a foundation that seeks to act as a major actor in the social policy scenario of infant-juvenile attendance together with the State. Abrinq's a representative 
organization of the civil society sphere to debate issues on the reality of childhood and adolescence as well as over the formulation, implementation and evaluation of public policies that defense of constitutional rights. Among its acting proposals, the support for policy makers and implementations to plan, execute and evaluate infantjuvenile attendance policies; the follow up the budgeting process and its execution, qualifying public debate and promoting the policy's social control [10].

Therefore, this case we can observe that a participation of society has been highlighted due its capability of providing qualified information about social demands and efficiently acting on public activities execution destined to social demands.

On the this hand, we identified the Abrinq Foundation at a crossroad between the actions of groups searching for a private interest dispute in the public space and those of groups that refused to abandon the State and aim the legitimacy of interests pertinent to citizens. However, there are groups and organizations that criticize the inefficiency of the State, putting the supremacy of the market and the civil society as potential substitutes of the State.

Fortunately, the political action of some organizations is characterized by dialogue, mobilization, participation inter-institutional that is aiming at qualification of the State, the monitoring of public policies, the reinforcement of the governmental management for attendance policy for child, adolescent and the reinforcement of the civil society.

In summary, this ambivalent situation has represented the politics disputes existent in the public sphere and also in the actions of social organizations from third sector and from of market services. Thus, this study reaffirms our research hypotheses, reiterating others studies results in the area.

\section{Conclusions}

Twenty years after the conquest of rights allocated in the Child and Adolescent's Statute, the system of Right Granting holds the challenge of promoting defense policies and attention in the attendance of infant-juvenile rights. In this scenario, it observed a significant rise to social participation through of the organizations third sector, especially those related to policies of attendance to children and adolescents (education, assistance and health).

This study sheds light over some possibilities of relations between State and new social actors that attend social policies. Such relations can be presented as complementary (co-manager in the State's power and decision structures, or in execution and public service networks) or as public control, Ombudsman and even as a State substitute.

The increase of this actors' presence in the public sphere of infant-juvenile attendance policies has been representing the demand for new responsibilities over the State, for instance, accountability, necessity of management and control public and private entities in their several assessment levels.
In this matter it is our responsibility to emphasize the decisive role that lays upon the State to grant a social contract which by its authority and/or consensus, is able to assume the democratic mediation in order to reform (technically, politically and culturally) the public section in a new ethnic orientation towards other society's sectors able to represent a political and social consensus around welfare issues.

In the same way, the difficulties consist of creating intersectorial policy among several social policies; guarantee a communication and an integrated communication network, transparency of actions, universality and integration of this population's attendance.

Finally, this study also reveals an important function of third sector, its inductor role of activities destined to infant-juvenile attendance. In the modern social movement of public control through the creation of public spaces that allow strong presence and pressure from the society on the decision-making, some organizations strengthen not only non-state spaces, but also public comanagement spaces.

It means spaces of consensus construction necessary for decision-making, involving power learning and the dealing with public issues, which requires the participation of the society in the power.

\section{References}

[1] PEREZ, J. R. R.; PASSONE, E. F. (2010) Políticas sociais de atendimento às crianças e aos adolescentes no Brasil, Cadernos de Pesquisa, São Paulo, v. 40, n. 140, Aug. Available from <http://www.scielo.br/scielo.php. Access on 27 Jan. 2012.

[2] PILOTTI, F; RIZZINI, I. (Orgs.) (1995), A arte de governar crianças: a história das políticas sociais, da legislação e da assistência à infância no Brasil. Rio de Janeiro: Instituto Interamericano Del Nino, p. 99-168.

[3] BROOKS, A. C. (2004), Evaluating the Effectiveness of Nonprofit Fundraising, The Policy Studies Journal, v. 32, n. 3, p. 363-374.

[4] LANDIM, L. (1993), Defining the Nonprofit Sector: Brazil, Working Papers of the Johns Hopkins Comparative Nonprofit Sector Project, in SALAMON, L. M.; ANHEIER, H. K. Baltimore: The Johns Hopkins Institute for Policy Studies.

[5] ELMOORE, C. J., HULA, R. C. (2001), Emerging roles of nonprofit organizations: an introduction, Policy Studies Review, Winter, 18:4.

[6] ESPING - ANDERSEN, (1985), Power and Destributional Regimes. Politics\&Society, 14 (2): 223-255.

[7] TITMUSS, R. M., (1974). Social Policy.New York: Pantheon.

[8] DAGNinO,E. OLVERA, A.J., PANFICHI, A. (Orgs.)(2006), A disputa pela construção democrática na América Latina, São Paulo: Paz e Terra.

[9] PAOLI, M. C. (2002), Empresas e responsabilidade social: os elementos da cidadania no Brasil, in SANTOS, B. S. Democratizar a democracia I, Rio de Janeiro: Civilização Brasileira, p. 371-418.

[10] PASSONE, E. F. (2007), Políticas Sociais de Atendimento à Infância e Juventude: o caso da Fundação Abrinq. Mestrado em Educação (Campinas/São Paulo) Universidade Estadual de Campinas - Unicamp

[11] BRASIL. (1990), Estatuto da Criança e do Adolescente - ECA, Ministério da Justiça/UNICEF, Brasília: Distrito Federal.

[12] BRASIL. (1988). Constituição Federal, Brasil: Brasília.

[13] BRASIL - INSTITUTO BRASILEIRO DE GEOGRAFIA E ESTATÍSTICA (2005), As Fundações Privadas e Associações Sem Fins Lucrativos no Brasil, Série Estudos \& Pesquisas. InformaçãoEconômica, $N^{\circ}$. 8, 2ª ed., Brasília. 